\title{
ТЕОРІЯ ЛЕГІТИМНОСТІ МІЖНАРОДНОГО ПРАВА ТОМАСА ФРАНКА
}

\section{Висоцький Олександр Юрійович}

доктор політичних наук, професор,

Дніпровський національний університет ім. Олеся Гончара, м. Дніпро, Україна

ORCID: 0000-0003-0712-8499

vysalek@gmail.com
Надіслано:

12.03.2021

Рецензовано:

23.03.2021

Прийнято:

05.04.2021

Актуальність дослідження визначається фундаментальною роллю легітимності в міжнародному праві та їі недостатньою осмисленістю в наукових дослідженнях. Головна мета дослідження $є$ визначити особливості теорії легітимності міжнародного права Томаса Франка. Методологію дослідження $\epsilon$ герменевтичний підхід, що дав можливість розглянути концепцію легітимності в міжнародному праві Томаса Франка як результат його аргументативних стратегій та інтерпретативної діяльності щодо функціонування суб'єктів міжнародного права.

Головні висновки дослідження полягають в тому, що теорія легітимності Томаса Франка визначає легітимність властивістю міжнародних принципів, норм та інститутів унаслідок їх відповідності загальноприйнятим принципам правового процесу забезпечувати наявність прагнення до додержання вимог таких принципів у учасників міжнародної спільноти. Томас Франк доводить, що чинниками такої властивості $\epsilon$ детермінованість, символічна валідація, когерентність та дотримання. Значущість дослідження полягає у виявленні основних положень теорії легітимності міжнародного права Томаса Франка, які справили визначальний вплив на подальші дослідження легітимності в міжнародно-правовому процесі. Одним із важливих таких положень $\epsilon$ твердження про те, що держави в міжнародній системі вимушені діятина основі дотримання міжнародних норм, які вважають легітимними. Відповідно, міра легітимності цих норм $є$ певним запобіжником для будь-яких держав, щоб не допустити безмежне розповсюдження їх влади на світовій арені.

Ключові слова: теорія легітимності; міжнародне право; символічна валідація; міжнародні норми; міжнародний правовий процес; Томас Франк.

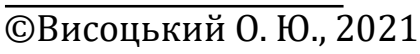




\section{Міжнародні відносини: теоретико-практичні аспекти \\ Випуск 7 (2021) \\ ISSN (print) 2616-745X; ISSN (online) 2616-7794}

\section{Вступ}

Легітимність відіграє фундаментальну роль у міжнародному праві, визначаючи його авторитет. Подібно до міжнародного права, джерелом легітимності $\epsilon$ воля держав. Проблема легітимності в міжнародному праві $\epsilon$ давньою. У вузькому правовому вимірі вона полягає у виборі правильної норми та принципів її належного застосування. У широкому значенні, легітимність не обмежується лише правовим виміром, охоплюючи моральний та деліберативний аспекти. Проблема легітимності особливо відчутно проявляється у складних випадках правозастосування, зокрема використання сили на міжнародній арені. Зростаюча тенденція впливу міжнародного права на національні законодавства, тиск на держави, що не дотримуються його норм, істотне розширення предметної сфери міжнародного права, також актуалізують цю проблему. Крім того, іноді спостерігаємо відсутність згоди суб'єктів міжнародного права щодо правомірності застосування його норм. Разом із тим, серед науковців та юристів немає визначеності щодо концептуального розуміння легітимності, що породжує проблему правозастосування норм міжнародного права. Усе це визначає значущість дослідження концепції легітимності. Особливого значення у цьому контексті набуває теорія легітимності одного із авторитетних американських дослідників Т.Франка, роботи якого, присвячені легітимності міжнародного права, стала своєрідною відправною точкою у дослідженні легітимаційної проблематики у сфері міжнародно-правових відносин.

\section{Аналіз останніх досліджень і публікацій}

Легітимності міжнародного права та, зокрема, теорії легітимності Т. Франка, присвячена незначна кількість публікацій. Це пов'язано з тим, що ця тема серед вчених-правознавців не $є$ магістральною. Серед останніх публікацій, що зачіпають досліджувану проблему, слід виділити роботи P. Вольфрума (Wolfrum, 2008), Б. Кабумби (Kabumba, 2018), Ю. Брунне та С. Тупа (Brunnée, Toope, 2010).

\section{Формулювання цілей статті}

У згаданих працях теорія Т. Франка не знайшла спеціального детального аналізу. Це і обумовило серед іншого доцільність даного дослідження.

Мета статті - визначити особливості теорії легітимності міжнародного права Томаса Франка.

\section{Виклад основного матеріалу дослідження}

Теорія легітимності Т.Франка $є$ найбільш помітною в міжнародному праві. Важливість його теорії обумовлена тим, що вона була однією із перших теорій легітимності в міжнародному праві та $€$ найбільш цитованою в наукових 
дослідженнях, присвячених цієї темі (Vysotskyi, 2020a; Vysotskyi, 2020b; Vysotskyi, 2017).

Теорія легітимності Т.Франка була представлена у низці статей, узагальнених у 1990 р. у монографії «Влада легітимності серед націй» (Franck, 1989). Наступні його роботи, зокрема «Справедливість у міжнародному праві та інститутах» (Franck, 1995), істотно не змінили його концепції, тому ми зосередимося на оригінальній праці.

Інтерес Т.Франка до розуміння легітимності в рамках міжнародного правопорядку заснований на класичних питаннях зобов'язання і дотримання, а також на впливі міжнародного права на міжнародні відносини: як можливо, щоб держави слідували міжнародному праву, коли немає центрального суверена, що забезпечує його дотримання? Це питання було центральним з моменту виникнення концепції права Джона Остіна (право як веління суверена) (Austin, 1998; Austin, 2005). Вплив концепції Дж. Остіна та їі наслідки для статусу міжнародного права як належної галузі права переслідували юристівміжнародників протягом тривалого періоду. Т. Франк будує свій розгляд легітимності на цьому тлі. Він хоче продемонструвати, що існує «міжнародна система правління», відмінна від простої міжнародної політики, яка підтримується без центрального суверена. Його центральна гіпотеза полягає в тому, що держави «зазвичай» дотримуються міжнародних правил, оскільки вони вважають їх легітимними (Franck, 1990, p. 20,33-35).

Т. Франк починає розгляд легітимності 3 викладу різних поглядів на неї в рамках соціальної та політичної теорії. Він ділить різні погляди на три табори. Перший табір розглядає легітимність як процес. Відповідно до цієї точки зору, норма або право легітимні щоразу, коли вони виникають за допомогою відповідної формальної процедури - це легітимність як правомірність (legal validity) (Franck, 1990, p. 17). Т. Франк включає М. Вебера до цього табору. Другий табір передбачає як процедурні, так і змістовні (матеріальні) елементи легітимності. Відповідно до цього, для визначення легітимності важливо не лише як норма, принцип чи розпорядження обираються чи приймаються, але також як вони можуть розглядатися у світлі об'єктивних даних та суб'єктивних позицій (Franck, 1990, p. 17). Найбільш яскравим представником цього табору Т. Франк вважає Юргена Габермаса. Третій табір фокусується на нормативних результатах легітимності - легітимність як змістовна (матеріальна) справедливість. Тут Т. Франк вказує на філософівнеомарксистів як на представників, але ними не обмежується. Представники цього табору вважають, що система має стверджувати себе через захищеність

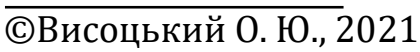




\section{Міжнародні відносини: теоретико-практичні аспекти \\ Випуск 7 (2021) \\ ISSN (print) 2616-745X; ISSN (online) 2616-7794}

3 позицій рівності, справедливості та свободи, які реалізуються через веління норм (Franck, 1990, p. 18).

Т.Франк визнає, що легітимність - це широке поняття, зокрема, що легітимність охоплює багато невід'ємних факторів, які пов'язані, але різнопланові та мають бути досліджені з посиланням на різні соціальні дані (Franck, 1990, p. 18). Він пропонує таке визначення легітимності: легітимність це властивість принципів чи норм нормотворчого інституту самостійно породжувати у адресатів пред'явлених норм прагнення до додержання їх вимог, оскільки адресати вважають, що норма або інститут виникли і діють відповідно до загальноприйнятих принципів правового процесу (Franck, 1990, p. 24).

Згодом Т.Франк виділяє і описує чотири «об'єктивні» властивості, що притаманні нормам: детермінованість, символічна валідація, когерентність і дотримання. Він стверджує, що «у тій мірі, в якій норма, або нормотворчий процес, проявляють ці чотири властивості, вони будуть чинити сильний вплив на держави, змушуючи їх підкорятися» (Franck, 1990, p. 49). I навпаки, з цього випливає, що «в тій мірі, в якій ці властивості відсутні, інститут буде легше ігноруватися, а норма легше обминатися державою, схильною переслідувати свої короткострокові власні інтереси» (Franck, 1990, p. 49) .

Перш ніж перейти до деталей цих властивостей, Т. Франк надає декілька уточнень. Зокрема, він визнає, що пропоновані властивості самі по собі недостатні для повного пояснення того, чому країни підкоряються міжнародним нормам. «Те, як створюються, інтерпретуються і застосовуються норми, $€$ частиною динамічного, широкого i складного набору соціальних явищ» (Franck, 1990, p. 49), - зазначає Т. Франк. «Легітимність - це не просто питання поєднання легкодоступних інгредієнтів і змішування їх в потрібних пропорціях» (Franck, 1990,p. 25). Крім того, він стверджує, що існує висока варіативність рівнів легітимності між різними нормами і що ступінь, в якій міжнародне право забезпечує їх дотримання, залежить від того, наскільки ці властивості проявляються в конкретній нормі (Franck, 1990, pp. 41-49).

Т. Франк також стверджує, що ідея вимірювання легітимності норм та інститутів «може бути підтримана тільки в тому випадку, якщо існує спільнота, яка погоджується з цим стандартом та застосовує його» (Franck, 1990, p. 204). У той час, коли не кожна норма міжнародної системи є легітимною, існування спільноти допускає можливість віддавати легітимні накази і примушувати до виконання зобов'язань різних її членів (Franck, 1990, p. 204).

Розглянемо чотирьохелементну типологію Т.Франка. Для нього детермінованість означає ступінь, в якій значення міжнародних норм чітко 
ідентифікується (Franck, 1990, p.52). Існує два способи, за допомогою яких міжнародна норма може досягти визначеності i, як наслідок, більшої міри легітимності. По-перше, визначеність потребує текстуальної ясності, що означає, що норма, з лінгвістичної точки зору, чітко визначає поведінку, яка допустима або неприпустима. Як наслідок, не повинно бути ніяких двозначностей щодо того, що очікується від суб'єктів міжнародного права, а нормі має бути легко слідувати. Частково спростовуючи відомий вислів Л. Вітгенштейна про те, що «жоден спосіб дій не може бути визначений правилом, тому що кожен спосіб дій може бути складений відповідно до правила» (Wittgenstein, 2018, p. 130), Т.Франк стверджує, що існують ступені детермінованості (Franck, 1990, p. 56). Як приклад норм, що високо детерміновані та для яких з високим ступенем відповідності може бути визначена поведінка, та, відповідно, легітимність, Т. Франк згадує юрисдикції судів у відкритому морі, територіальних водах і портах, як встановлено в Конвенції ООН з морського права (Franck, 1990, p. 60). По-друге, визначеність, на думку Т. Франка, може бути досягнута через процес прояснення. Ідея полягає в тому, що норма, незважаючи на те, що вона текстуально неясна або розпливчаста, може бути визначена в процесі тлумачення, здійснюваного компетентним органом або на індивідуальній основі (Franck, 1990, p. 61).

Чи працюватиме процес роз'яснення чи ні, залежатиме від того, чи сприймають члени міжнародної спільноти цей процес як легітимний. Отже, його успіх буде залежати від того, хто інтерпретує норми, від походження компетентного органу і від узгодженості принципів, що застосовуються при інтерпретації норми (Franck, 1990, p. 61). Т. Франк далі стверджує, що норми, взагалі кажучи, мають тенденцію рухатися до детермінованості. Як приклад він розглядає заборону на застосування сили в ст. 2 (4) Статуту ООН. Т. Франк стверджує, що в той час як до введення цієї статті законність війни грунтувалася на тому, чи вважалася вона «справедливою» або «несправедливою», ст. 2(4) являє собою крок до визначення в регулюванні війни, оскільки відповідно до цієї статті застосування сили не є прийнятним (Franck, 1990, p.62). Отже, завдяки текстуальній ясності або конкретизації в кожному конкретному випадку норма може набути визначеності i, таким чином, стати більш легітимною. Т.Франк попереджає, що детермінованість не є бінарним поняттям, а може бути задоволена тільки в тій чи іншій мірі. Отже, рівень легітимності, що приписується цієї нормі, буде відповідно варіюватися (Franck, 1990,p. 56).

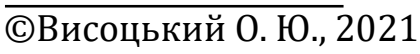




\section{Міжнародні відносини: теоретико-практичні аспекти \\ Випуск 7 (2021) \\ ISSN (print) 2616-745X; ISSN (online) 2616-7794}

Другим виміром чотирьохелементної типології Т. Франка є символічна валідація. Цей аспект легітимності відноситься до культурних і антропологічних вимірів права. Т.Франк стверджує, що здатність «проявляти тягу до добровільного підпорядкування» заснована на здатності спілкуватися не стільки через зміст, скільки 3 позиції автентичності: це може бути «добровільно визнана автентичність норми або творця норм, або, іноді, автентичність (валідність), дарована одержувачу символічного повідомлення (Franck, 1990, p.91). Іншими словами, воля слідувати авторитету може бути заснована на вірі, яка, в свою чергу, може бути заснована на певній традиції або інших факторах. Символічна валідація відбувається згодом, коли сигнал використовується в якості знаку для отримання відповідності наказу (Franck, 1990, p. 92). Т. Франк ілюструє свою точку зору прикладом виконання національного гімну. Своїм співом і візуальним втіленням державний гімн зміцнює відносини між державою і його громадянами, а також їх правами та обов'язками. Т. Франк уточнює своє поняття символічної валідації докладним обговоренням ритуалу і родоводу. Ритуал розглядається ним як особлива форма символічної валідації. Це тягне за собою церемонії, часто містичні, які дають невисловлені причини для виконання наказів людей і установ (Franck, 1990, р. 92).

Для Т.Франка ритуал служить, щоб повідомляти i стверджувати переконання і цінності системи. Він зміцнює норми та структуру влади громади, охоплюючи та залучаючи внутрішню групу та виключаючи зовнішню групу, яка не може (або не хоче) розділяти або розуміти символічний комунікаційний код. Отже, це спосіб підтвердження загальних зв'язків та легітимації не тільки конкретної дії чи норми, але й самої системи, всього набору її норм та розподілу ролей і повноважень (Franck, 1990, p. 93).

Т. Франк далі розглядає родовід як ще один спосіб символічної валідації. Це поняття спирається на ідею «глибокої вкоріненості» між нормою та інститутом, що створює норму. У більш точних термінах родовід підкреслює поважні історичні та соціальні витоки і спадкоємність стандартів норм, а також нормотворчих або правозастосовуючих інститутів. Він взаємно пов'язує права і обов'язки в понятті поважного, засвідченого статусу, що заслуговує особливої поваги (Franck, 1990, p. 94).

Для посилення символічної сили родоводу використовуються символи високої культурно-антропологічної значущості. Таким чином, символічна валідація спонукає підкорятися через ритуал, родовід або їх комбінацію. Т. Франк визнає, що символічна валідація має силу тільки за певних обставин і не може 
бути створена довільно. Зокрема, він стверджує, що сигнали, які використовуються для символічної валідації, $\epsilon$ потужними в тій мірі, в якій вони сприймаються як справжні тими, кому вони адресовані. Коли сигнали перестають символічно пересилатися на те, що сприймається як історична, соціальна, політична або метафізична реальність, вони перестають підтверджувати і замість цього втрачають свою магію. у сірій зоні, коли сигнали відносяться до неоднозначної реальності, вони іноді можуть бути ефективними не тільки для підтвердження, але і для посилення цієї реальності. Але там, де реальність зрозуміла, інститути, наділені символічною валідацією, цілком адекватно чинять опір тиску зловживання - і тим самим зменшують свою владу дарувати легітимність, вдаючись до помилкових сигналів (Franck, 1990, p. 134).

Третій елемент типології Т. Франка - когерентність (узгодженість). Розвиваючи думку про те, чому символічні сигнали можуть зазнати невдачі, він називає некогерентне використання в якості однієї з можливих причин. Як приклад, некогерентності він посилається на прийняття України як державичлена ООН до розпаду Радянського Союзу, коли Україна ще не виконала вимоги для отримання права на членство. Згідно з Т. Франком, когерентність дозволяє легітимізувати норму, принцип або інститут імплементації, оскільки вона забезпечує розумний зв'язок між нормою або застосуванням норми 3 1) його власною принциповою метою; 2) принципами, що раніше використовувалися для вирішення аналогічних проблем; i 3) рештками принципів, що використовуються для вирішення різних проблем (Franck, 1990, pp. 147-148).

Іншими словами, якщо норма не застосовується когерентно, тобто якщо вона не може бути підтверджена «перевіркою когерентного узагальнення», іiі легітимність буде підірвана. Т.Франк далі розрізняє когерентність і послідовність. Зокрема, він стверджує, що протиріччя не повинні бути некогерентними доти, поки існує «раціональна» основа для відмінності, тобто існує внутрішній, зазвичай логічний, зв'язок не тільки між нормою, iii різними частинами та іiі метою, але також між конкретною нормою, iї основоположним принципом та принципами, що лежать в основі інших правил суспільства (Franck, 1990, р. 153).

Нарешті, Т. Франк розглядає дотримання як четвертий елемент свого пояснення легітимності. Введення принципу дотримання пов'язане з ідеєю про те, що міжнародне право $\epsilon$ належною системою, а це означає, що існують первинні норми, вторинні норми і навіть вище - норма визнання.

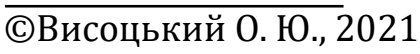




\section{Міжнародні відносини: теоретико-практичні аспекти \\ Випуск 7 (2021) \\ ISSN (print) 2616-745X; ISSN (online) 2616-7794}

Це суперечить позиції Г. Гарта, який стверджує, що міжнародне право нагадує примітивне плем'я, що має тільки первинні норми (Hart, 2012, pp.77-96). Т.Франк стверджує, що міжнародне право $\epsilon$ належною системою в силу наявності динаміки взаємності, яка, в свою чергу, спонукає до добровільного дотримання норм державами, що належать до тієї чи іншої спільноти. Точніше, держави слідують міжнародним нормам, тому що це ціна, яку потрібно заплатити за приналежність та прийняття в якості частини спільноти держав (Franck, 1990, pp. 196-199). Це відповідає вищій нормі визнання, з якої випливають формальні джерела міжнародних зобов'язань та вторинні норми.

Переходячи до співвідношення між міжнародним правом як системою та дотриманням, Т.Франк підкреслює вертикальний зв'язок між первинною нормою зобов'язання та ієрархією вторинних норм, які визначають джерела норм та встановлення нормативних стандартів, що своєю чергою визначають, як норми повинні створюватися, тлумачитися і застосовуватися (Franck, 1990, p.184). Він стверджує, що норми будуть дотримуватися більше, якщо вони є продуктом належного правового процесу (Franck, 1990, pp. 184-190). Зокрема, Т.Франк стверджує, що якщо норми, створені міжнародною правовою системою, можуть бути виправдані вторинними нормами цієї системи, то їх нормативна сила буде більше. Наприклад, ст.ст. 31-33 Віденської конвенції про право міжнародних договорів, які регулюють тлумачення міжнародно-правових норм, можуть підтвердити первинну норму, якщо вона була витлумачена відповідно до цих статей. У свою чергу, вторинні норми також можуть бути підтверджені іншими загальними принципами, такими як раcta sunt servanda («угоди мають дотримуватися»), що $є$ частиною принципу визнання (Franck, 1990,p.202). Це вже натякає на той факт, що легітимність вищого принципу визнання не може бути виправдана іншими нормами, а тільки поведінкою націй, що виявляється в їх вірі в дійсність вищих принципів як непорушних передумов для міжнародної концепції належного правового процесу (Franck, 1990, p. 194).

Нарешті, Т.Франк підкреслює відмінність між легітимністю і справедливістю. Зокрема, він стверджує, що легітимність не повинна «змішуватися» зі справедливістю, його «симбіотичним кузеном». Для Т.Франка легітимність означає сприйняття, тоді як справедливість орієнтована на результати. На його думку, легітимність норми або принципу не обов'язково забезпечує його справедливість, i, навпаки, справедливість норми не обов'язково корелює зі ступенем їі легітимності. Проте, використання слова 
«симбіотичний» покликане передати ідею про те, що принципи справедливості потребують інфраструктурної підтримки з боку принципів легітимності (Franck, 1989).

\section{Висновки}

Визначаючи, що легітимність $€$ властивістю міжнародних принципів, норм та інститутів у силу їх відповідності загальноприйнятим принципам правового процесу забезпечувати наявність прагнення до додержання їх вимог в учасників міжнародної спільноти, Т. Франк доводить, що чинниками такої властивості $\epsilon$ детермінованість, символічна валідація, когерентність і дотримання. Головна ідея Т. Франка полягає в тому, що міжнародна система правління існує без центрального суб'єкта. У цій системі держави вимушені діяти на основі додержання міжнародних норм, які вважають легітимними. Відповідно, міра легітимності цих норм $є$ певним запобіжником для будь-яких держав, щоб не допустити безмежне розповсюдження їх влади на світовій арені.

Дослідження легітимності у міжнародному праві передбачає також осмислення інших іiі теоретичних рецепцій, а також висвітлення впливу іï концептуалізацій на правозастосування.

\section{References:}

1. Austin, J. (1998). The province of jurisprudence determined. Aldershot; Brookfiedl, USA: Dartmouth Publishing.

2. Austin, J. (2005). Lectures on jurisprudence, or, The philosophy of positive law. New Jercy: Lawbook Exchange.

3. Brunnée, J. (2010). Legitimacy and legality in international law: an interactional account. Cambridge; New York: Cambridge University Press.

4. Franck, Th .M. (1995). Fairness in international law and institutions. Oxford: Clarendon Press ; New York : Oxford University Press, 1995. XXXVI, 500 p.

5. Franck, Th. M. (1989). “Justice in the International System'. Michigan Journal of International Law, Vol. 10, issue 1, pp. 127-161.

6. Franck, Th. M. (1990). The power of legitimacy among nations. New York; Oxford: Oxford University Press.

7. Hart, H. L. A. (2012). The concept of law. Oxford, United Kingdom: Oxford University Press.

8. Kabumba, B. (2018). Soft law and legitimacy in international law. Ntinda Uganda: Development Law Publishing Company Limited.

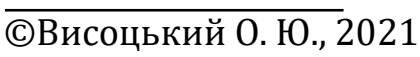


9. Vysotskyi, O. Yu. (2017). 'Lehitymatsiia' [Legitimation]. Velyka ukrainska yurydychna entsyklopediia. Vol. 2: Filosofiia prava. Kharkiv: Pravo. pp. 398-401.

10. Vysotskyi, O. Yu. (2020a). 'Lehitymnist u mizhnarodnomu pravi: sutnist ta struktura' [Legitimacy in international law: essence and structure]. Sotsialnohumanitarni doslidzhennia ta innovatsiina osvitnia diialnist: Materialy II Mizhnarodnoi naukovoi konferentsii. 26-27 chervnia 2020, Dnipro. Dnipro: SPD «Okhotnik». pp. 249-251.

11. Vysotskyi, O. Yu. (2020b). 'Kontseptsiia lehitymnosti v mizhnarodnomu pravi' [The concept of legitimacy in international law]. Osvita $i$ nauka $u$ minlyvomusviti: problemy ta perspektyvy rozvytku: Materialy II Mizhnarodnoi naukovoi konferentsii. 27-28 bereznia 2020, Dnipro. Part II. Dnipro: SPD «Okhotnik». pp. 378-379.

12. Wittgenstein, L. (2018). Philosophical Investigations / translated from German by L. Dobroselskij. Moscow: Izdatel'stvo AST.

13. Wolfrum, R. (2008). 'Legitimacy in International Law from a Legal Perspective: Some Introductory Considerations'. Legitimacy in International Law. Berlin; New York: Springer. pp. 1-24. 


\section{THOMAS FRANCK'S THEORY OF THE INTERNATIONAL LAW LEGITIMACY}

\section{Vysotskyi Oleksandr}

Doctor of Political Sciences, Professor,

Dnipro National University named after Oles Honchar,

Dnipro, Ukraine

ORCID: 0000-0003-0712-8499

vysalek@gmail.com

The relevance of the study is determined by the fundamental role of legitimacy in international law and its lack of meaning in scientific research. The main purpose of the study is to determine the features of the theory of the international law legitimacy by Thomas Franck. The methodology of the study is a hermeneutical approach, which made it possible to consider the concept of legitimacy in international law by Thomas Franck as a result of his argumentative strategies and interpretative activities regarding the functioning of subjects of international law.

The main conclusions of the study are that Thomas Franck's theory of legitimacy defines legitimacy as a property of international principles, norms and institutions due to their compliance with the generally accepted principles of law process and the desire to comply with the requirements of such principles among the participants of the international community. Thomas Franck argues that such factors are determinism, symbolic validation, coherence, and compliance. The significance of the study is determined by the identification of the main provisions of the theory of legitimacy of international law by Thomas Franck, which significantly influenced further studies of legitimacy in the international law process. One important such provision is the assertion that nations in the international system are forced to act on the basis of compliance with international norms that are considered legitimate ones. Accordingly, the measure of the legitimacy of these norms is a kind of safeguard for any nations to prevent the unlimited spread of their power on the world stage.

Key words: legitimacy theory; international law; symbolic validation; international norms; international law process; Thomas Franck. 


\title{
ТЕОРИЯ ЛЕГИТИМНОСТИ МЕЖДУНАРОДНОГО ПРАВА ТОМАСА ФРАНКА
}

\author{
Высоцкий Александр Юрьевич \\ доктор политических наук, профессор, \\ Днепровский национальный униаерситет им, Олеся Гончара, \\ 2. Днепро, Украина \\ ORCID: 0000-0003-0712-8499 \\ vysalek@gmail.com
}

Актуальность исследования определяется фундаментальной ролью легитимности в международном праве и ее недостаточной осмысленностью в научных исследованиях. Главная цель исследования - определить особенности теории легитимности международного права Томаса Франка. Методологией исследования является герменевтический подход, давший возможность рассмотреть концепцию легитимности в международном праве Томаса Франко как результат его аргументативных стратегий и интерпретативной деятельности в отношении функционирования субъектов международного права.

Главные выводы исследования заключаются в том, что теория легитимности Томаса Франка определяет легитимность свойством международных принципов, норм и институтов в следствии их соответствия общепринятым принципам правового процесса обеспечивать наличие стремления к соблюдению требований таких принципов у участников международного сообщества. Томас Франк доказывает, что факторами такого свойства являются детерминированность, символическая валидация, когерентность и соблюдение. Значимость исследования заключается в выявлении основных положений теории легитимности международного права Томаса Франка, которые оказали определяющее влияние на дальнейшие исследования легитимности в международно-правовом процессе. Одним из важных таких положений является утверждение о том, что государства в международной системе вынуждены действовать на основе соблюдения международных норм, которые считаются легитимными. Соответственно, мера легитимности этих норм является неким предохранителем для любых государств, чтобы не допустить безграничное распространение их власти на мировой арене.

Ключевые слова: теория легитимности; международное право; символическая валидация; международные нормы; международный правовой процесс; Томас Франк. 